\title{
Light and Scanning Electron Microscopic Studies on the Intestine of Grass Carp (Ctenopharyngodon idella): I-Anterior Intestine
}

\author{
Doaa M Mokhtar*, Enas A Abd-Elhafez and Hassan AH
}

Department of Anatomy and Histology, Faculty of Vet. Medicine, Assuit University, Egypt

\begin{abstract}
The present work was carried out on 20 specimens of grass carp in order to observe the morphological features of intestine. The present study showed that the intestine was long, which may help in retention of food for a longer period of time to ensure proper digestion. Also, the percent of relative gut length (RGL) of grass carp was $1.92 \%$. This RGL with a large intestinal diameter of this species allowing increase the storage capacity of food. The intestine of grass carp were divided into anterior, posterior intestine and rectum. There were no intestinal villi or multicellular intestinal glands in any regions of intestine. The most important features of anterior intestine were a wide diameter of the lumen and a great number and height of mucosal folds. The anterior intestine was lined by simple columnar epithelium, intercalated with goblet cells, wandering lymphocytes and enteroendocrine cells. Scanning electron microscopy, revealed presence of long wavy mucosal folds that formed of enterocytes covered with numerous microvilli, intermingled with numerous openings for goblet cells.
\end{abstract}

Keywords: Intestine; Grass carp; Goblet cells; Enteroendocrine cells

\section{Introduction}

The grass carp or white amur (Ctenopharyngodon idella) is a large cyprinid fish characterized by toothless mouth. They are native to large Asian rivers such as Amur River Basin in Russia and the West River in China [1]. Grass carp have been extensively cultured in many areas of the world. It is fast growing herbivorous fish, it usually feeds on grasses or other aquatic vegetations and can be grown together with other fish species [2].

The gastrointestinal tract of teleosts has attracted considerable interest because of its diversity of form as related to diet. Therefore, the gross morphology and histology of the tract has long been a topic of investigation, either simply descriptive $[3,4]$ or related to feeding habits $[5,6]$. However, diversity in descriptive terminology presents difficulties in performing an exact comparison of the histological structure of many species.

The intestine of numerous fish species is generally consisted of mucosa, submucosa, muscularis and serosa [7]. Results in previous studies have indicated that some differences of histological structures of intestine among fish are related to feeding habits, food, age, body shape and weight $[8,9]$.

The aim of the present study is to describe the morphology of intestine of grass carp (Ctenopharyngodon idella), using light and electron microscopy. This may provide a comparative basis for future studies of digestion, absorption and feeding pattern of this species, as well as contribution to the development of fish farming.

\section{Materials and Methods}

\section{Source of samples}

The materials employed in this study consisted of randomly obtained 20 adult specimens of both sex of the grass carp (Ctenopharyngodon idella). The materials were collected from fish farm in El-Minea during the year. The specimens were $37.20+4.0 \mathrm{~cm}$ in standard length and $421.60+8.70 \mathrm{~g}$ in body weight.

\section{Gross morphology}

Gross morphology was done for the shape, length and arrangement of the intestine.
Relative gut length (RG L) \%=the absolute length of gastrointestinal tract (the distance between the proximal end of the oesophagus to the anus $(\mathrm{cm})) \backslash$ standard length of the body $(\mathrm{cm}) \times 100[10]$.

\section{Histological analysis}

The samples for histological examination were dissected as soon as possible from anterior portion of intestine of grass carp through a middle incision in the abdominal cavity. All samples were dissected at 1 $\times 1 \times 0.05 \mathrm{~cm}$ and were immediately fixed in Bouin's fluid for 22 hours. The fixed materials were dehydrated in an ascending series of ethanol, cleared in methyl benzoate and then embedded in paraffin wax. Transverse and longitudinal paraffin sections at 5-8 $\mu \mathrm{m}$ in thickness were cut and stained with Harris haematoxylin and Eosin for general histological examination [11].

\section{Histochemical analysis}

Representitive sections were stained with PAS for detection of neutral mucins, alcian blue for acidic mucins and combined alcian blue- PAS technique for acid and neutral mucins. In additions some sections were stained with Grimelius silver method for argyrophilic cells [11].

\section{Semi-thin sections}

Small pieces 2.0-3.0 $\mathrm{mm}$ long from anterior portion of intestine of grass carp were placed in $2.5 \%$ cold glutaraldehyde in phosphate buffer ( $\mathrm{pH} 7.2$ ) for 24 hours. The pieces were washed twice in $0.1 \mathrm{M}$ phosphate buffer 3 and then post-fixed in $1 \%$ osmium tetraoxide, in the

${ }^{*}$ Corresponding author: Doaa M Mokhtar, Master, PhD, Department of Anatomy and Histology, Faculty of Vet. Medicine, Assuit University, Egypt, Tel: +20-882357007; E-mail: doaamokhtar33@yahoo.com

Received June 17, 2015; Accepted July 06, 2015; Published August 16, 2015

Citation: Mokhtar DM, Abd-Elhafez EA, Hassan AH (2015) Light and Scanning Electron Microscopic Studies on the Intestine of Grass Carp (Ctenopharyngodon idella): I-Anterior Intestine. J Aquac Res Development 6: 374. doi:10.4172/21559546.1000374

Copyright: (c) 2015 Mokhtar DM, et al. This is an open-access article distributed under the terms of the Creative Commons Attribution License, which permits unrestricted use, distribution, and reproduction in any medium, provided the original author and source are credited. 
Citation: Mokhtar DM, Abd-Elhafez EA, Hassan AH (2015) Light and Scanning Electron Microscopic Studies on the Intestine of Grass Carp (Ctenopharyngodon idella): I-Anterior Intestine. J Aquac Res Development 6: 374. doi:10.4172/2155-9546.1000374

Page 2 of 5

same buffer. The post-fixed pieces were dehydrated in graded alcohols and embedded in araldite resin. Thin sections $(1 \mu \mathrm{m})$ in thickness were stained with $1 \%$ toluidine blue.

\section{Scanning electron microscopy}

Formaldehyde- fixed specimens of anterior intestine of grass carp were washed in $0.1 \mathrm{M}$ cacodylate buffer for $1 \mathrm{~h}$. Then transferred to a $1 \%$ solution of tannic acid for $2 \mathrm{~h}$ at room temperature. The pieces then were washed again in buffer and post fixed for $2 \mathrm{~h}$ in $1 \%$ osmium tetraoxide. The post fixed materials were washed, dehydrated in a series of increasingly concentrated solutions. They were then mounted on aluminum stubs and sputter- coated with gold/palladium for $3 \mathrm{~min}$. The specimens were examined with a JEOL. JSM-5400 LV scanning electron microscope.

\section{Morphometrical measurements}

Morphometric study was applied on representative stained sections of the anterior intestine by using Image analysis system (Leica Q500MC). Including:

- Diameter of the anterior intestine.

- $\quad$ Thickness of the wall.

- Diameter of the lumen.

- $\quad$ Thickness of the tunica mucosa.

- Height and width of the mucosal folds.

- Height of the surface epithelium.

- $\quad$ Thickness of the submucosa.

- Thickness of the tunica mucularis.

\section{Results}

\section{Gross morphology}

The grass carp had an elongate, moderately compressed yellowishgreen body with large scales. The head was broad and the mouth was

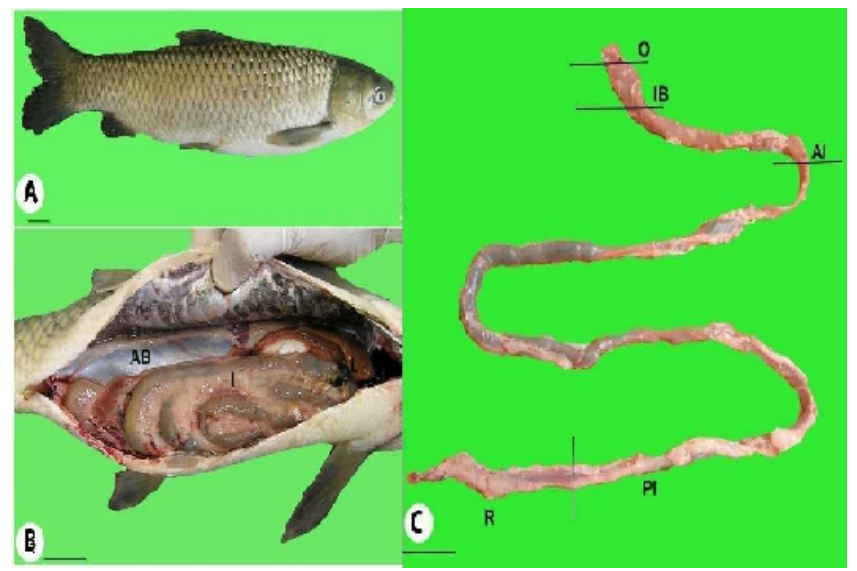

Figure 1: Morphology of grass carp intestine. A: Lateral view of grass carp (Bar $=0.67 \mathrm{~cm}$ ). B: Ventral view of grass carp showing the gastrointestinal tract in the abdominal cavity. Notice the coiling of the intestine (I), which is located ventral to the air bladder $(A B)$. The upper part of tract was overlapped by the liver $(\mathrm{L})$. (Bar=0.81 cm). C: Photograph of the gastrointestinal tract of grass carp. Oesophagus $(\mathrm{O})$ connected to the intestinal bulb (IB). The intestine is divided into anterior intestine $(\mathrm{Al})$, posterior intestine $(\mathrm{PI})$ and rectum $(\mathrm{R})$. $($ Bar $=0.80 \mathrm{~cm})$

\begin{tabular}{|l|c|}
\hline Measurements & Grass carp \\
\hline Body weight $(\mathrm{gm})$ & $421.60 \pm 8.70$ \\
\hline Total length of fish $(\mathrm{cm})$ & $40.60 \pm 6.21$ \\
\hline Standard length of fish $(\mathrm{cm})$ & $37.20 \pm 4.0$ \\
\hline Total length of gastrointestinal tract $(\mathrm{cm})$ & $71.50 \pm 4.80$ \\
\hline Length of intestine (cm) & $68.44 \pm 3.40$ \\
\hline Diameter of intestine (cm) & $0.77 \pm 0.13$ \\
\hline Relative gut length (RGL) (\%) & 1.92 \\
\hline
\end{tabular}

Table 1: Biometrical measurements of grass carp (the values were represented by mean \pm standard error).

\begin{tabular}{|l|l|}
\hline Measurements & Anterior intestine of grass carp \\
\hline Diameter of the organ $(\mu \mathrm{m})$ & $6546.22 \pm 41.15$ \\
\hline Thickness of the wall $(\mu \mathrm{m})$ & $2344.23 \pm 6.05$ \\
\hline Diameter of the lumen $(\mu \mathrm{m})$ & $1857.76 \pm 37.1728 .37 \%$ \\
\hline Thickness of mucosa $(\mu \mathrm{m})$ & $1951.42 \pm 28.3083 .24 \%$ \\
\hline Number of mucosal folds/cross section & $58.85 \pm 9.0$ \\
\hline Height of mucosal folds $(\mu \mathrm{m})$ & $1901.07 \pm 7.0681 .09 \%$ \\
\hline Width of mucosal folds $(\mu \mathrm{m})$ & $160.84 \pm 11.52$ \\
\hline Height of the epithelium $(\mu \mathrm{m})$ & $39.16 \pm 2.251 .67 \%$ \\
\hline Thickness of submucosa $(\mu \mathrm{m})$ & $69.67 \pm 2.342 .97 \%$ \\
\hline Thickness of muscularis $(\mu \mathrm{m})$ & $356.46 \pm 8.2215 .20 \%$ \\
\hline
\end{tabular}

Table 2: Morphometrical analysis of anterior intestine of grass carp as well as their relation (\%) to the wall measurements: (the values were represented by mean \pm standard error).

small and subterminal in position without barbels (Figure 1A). The relative gut length (\%) that represented the length of digestive tract to standard body length was $1.92 \%$ (Table 1 ). The intestine was entirely separated from the air bladder, and occupied the ventral position of the body cavity. The intestine of grass carp was a simple coiled tube, showed many convolutions (Figure 1B), and divided into anterior, middle and rectal intestine as in catfish (Figure 1C). The intestine of grass carp was long; the mean length was $68.44+3.40 \mathrm{~cm}$. The mean diameter of anterior intestine was $0.77+0.13 \mathrm{~cm}$ (Table 1).

\section{Histological analysis}

The intestine of grass carp was divided into three portions according to thickness of the wall, length of mucosal folds and thickness of muscularis; anterior, middle (posterior) and rectum. The anterior intestine was characterized by a wide diameter that its mean diameter was $6546.22+41.15 \mu \mathrm{m}$ and in the mean thickness of the wall was 2344.23+6.05 $\mu \mathrm{m}$ (Table 2). Light microscopic observations revealed that the wall of anterior intestine of grass carp was composed of tunica mucosa, tunica submucosa, tunica muscularis and tunica serosa.

The mean thickness of the tunica mucosa was $1951.42+28.30 \mu \mathrm{m}$ that constituted about $83.24 \%$ of the thickness of the wall. The mean diameter of the lumen was $1857.76+37.17 \mu \mathrm{m}$, which represented about $28.37 \%$ of the diameter of the organ. The mean number of mucosal folds was 58 (Table 2). There were no intestinal villi in intestine of grass carp. The mucosal folds appeared swollen and bulged towards the lumen in the form of wavy longitudinal, tall folds (Figure 2A). The mean height of mucosal folds was $1901.07+7.06 \mu \mathrm{m}$, which represented about $81.09 \%$ of the thickness of the wall. The mean width of mucosal folds was $160.84+11.52 \mu \mathrm{m}$ (Table 2).

The mean height of epithelium was $39.16+2.25 \mu \mathrm{m}$ (Table 2). It consisted of enterocytes (simple columnar epithelium) and contained numerous isolated goblet cells. Goblet cells were regularly oval in shape and appeared somewhat deeper in position, connected to the surface 
Citation: Mokhtar DM, Abd-Elhafez EA, Hassan AH (2015) Light and Scanning Electron Microscopic Studies on the Intestine of Grass Carp (Ctenopharyngodon idella): I-Anterior Intestine. J Aquac Res Development 6: 374. doi:10.4172/2155-9546.1000374

Page 3 of 5

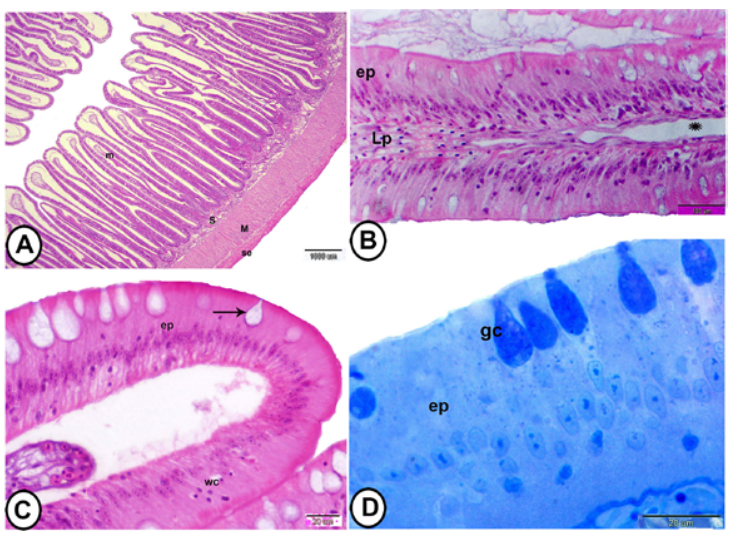

Figure 2: Histological analysis and semithin sections of anterior intestine of grass carp. A: the wall of anterior intestine of grass carp was constituted of folded mucosa $(\mathrm{m})$, submucosa $(\mathrm{S})$, muscularis (M) and serosa (se) (Haematoxylin and Eosin). B: The mucosal fold of anterior intestine showing epithelium (ep) that consisted of simple columnar epithelium with goblet cells and lamina propria (Lp). Notice the presence of large lymphatic vessels $\left(^{*}\right)$ (Haematoxylin and Eosin). C: The simple epithelium (ep) of anterior intestine showing goblet cells (arrow) and wandering cells (wc). (Haematoxylin and Eosin). D: Semithin section of simple columnar epithelium (ep) of the anterior intestine of grass carp with goblet cells (gc). (Toluidine blue)

by neck and small pores. Wandering cells were more common around the bases of columnar cells and might migrate to the free border of the cells (Figures 2B and 2C). Lamina propria was formed of loose connective tissue layer that extended into mucosal folds. It contained collagenous fibers, fibroblasts, lymphocytes and smooth muscle fibers. Large lymphatic vessels were found in lamina propria and were easily identified as blank spaces under the epithelial layer. There were no traces of multicellular intestinal glands (Figure 2B).

The tunica submucosa was a thin layer of connective tissue, contained fine elastic fibers that found around the blood capillaries (Figure 2A). Its mean thickness was $69.67+2.34 \mu \mathrm{m}$ (Table 2). The tunica muscularis was consisted of thick inner circular and thin outer longitudinal smooth muscle fibers followed by thin tunica serosa (Figure 2A). The mean thickness of muscularis was $356.46+8.22 \mu \mathrm{m}$, which constituted about $15.20 \%$ of the thickness of the wall (Table 2).

\section{The semi-thin sections}

It showed that the mucosal epithelium was lined by simple columnar cells and goblet cells. Each columnar cell was long and slender contained large oval nucleus, which situated at the basal portion of the cell at variable height. These columnar cells were covered by numerous microvilli. The goblet cells consisted of apical expanded portion, contained positive toluidine blue muco substances that connected to the surface by small pores and narrow portion which contained narrow nucleus located at higher position than the nucleus of enterocytes (Figure 2D).

\section{Histochemical analysis}

The goblet cells were numerous, which made a continuous sheet and reacted intensely positive to PAS (Figure 3A), Alcian blue (Figure 3B), and combined PAS-Alcian blue (Figure 3C). Spindle-haped enteroendocrine cells were located between the columnar cells and reacted positively to Grimelius stain. Most of these cells reached to the lumen that may be an open type (Figure 3D).

\section{Scanning electron microscopic observations}

It revealed that the mucosa of the anterior intestine of grass carp was characterized by the presence of long irregular wavy folds (Figure $4 \mathrm{~A})$. The mucosal lining was supported by densely backed polyhedral columnar cells, intercalated with large number of goblet cells (Figure $4 \mathrm{~B})$. The apices of the epithelial cells were covered with prominent microvilli (Figure 4C). In Figure 4D the epithelial sheet had been

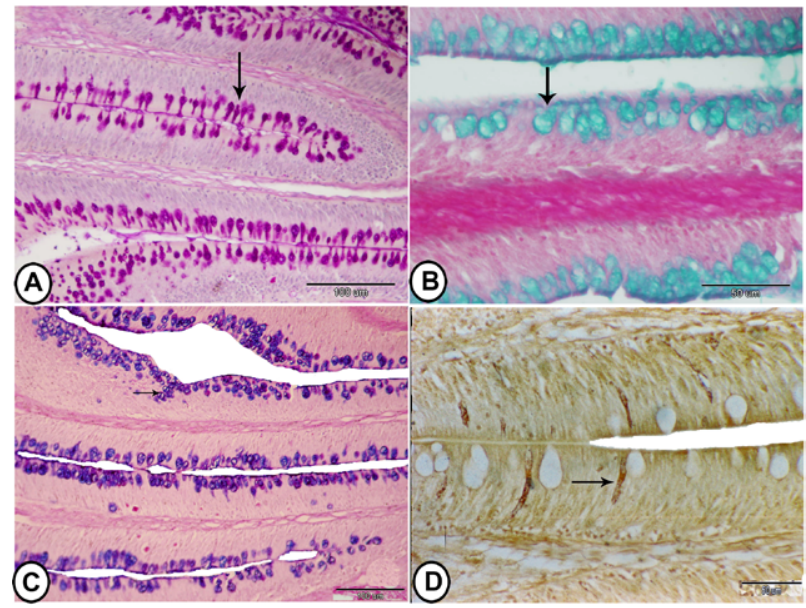

Figure 3: Histochemiical analysis of anterior intestine of grass carp. A: Positive reaction of goblet cells to PAS (arrowhead). B: positive reaction of goblet cells to Alcian blue (arrowhead).C: the epithelium of anterior intestine of grass carp showing PAS- and Alcian blue- positive goblet cells (arrow). (Combined AB and PAS). D: the epithelium of anterior intestine of grass carp showing oval- shaped enteroendocrine cells (arrow). (Grimelius)

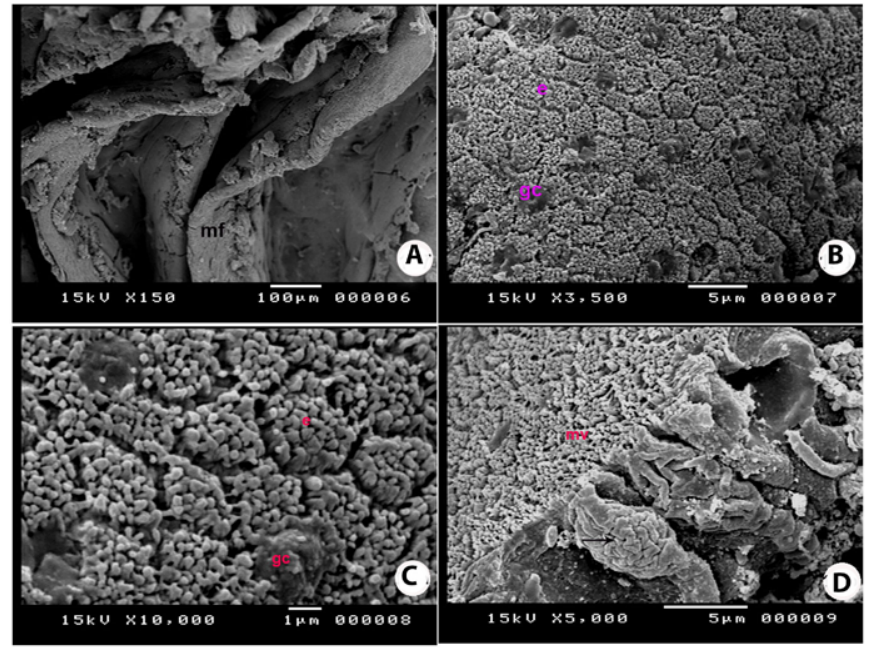

Figure 4: Scanning electron microscopy of the anterior portion of intestine. A: Scanning electron micrograph of the anterior intestine of grass carp showing long mucosal folds (mf). B: Scanning electron micrograph showing the surface polyhedral shaped enterocytes (e) and goblet cells (gc). C: Scanning electron micrograph of the surface polyhedral shaped enterocytes (e) of anterior intestine of grass carp, covered with microvilli. Notice the presence of large pores leading to goblet cells $(\mathrm{gc})$. D: Scanning electron micrograph of the damaged surface of anterior intestine of grass carp, covered with microvilli (mv). Notice presence of typical goblet cells (arrow). 
damaged and the individual enterocytes were clearly observed. The microvillous borders of these cells were clearly discernible as light bands at the tops of enterocytes. Also, typical goblet cells were observed between the columnar cells.

\section{Discussion}

Our results also revealed that the percent of relative gut length (RGL) of grass carp was approximately high. Albrecht MP et al. [6] recorded that high RGL values were in herbivorous species, whereas intermediate values were associated with omnivorous and low values in carnivorous ones. A functional explanation for the long gastrointestinal tract of herbivorous was that some components of the diet were slow to digest and required both a longer time and more extensive exposure to digestive enzymes. This phenomenon could be supported by the demonstration of large diameter of intestine of grass carp required for increasing the storage capacity of food.

In the current work, the most important feature of the anterior intestine of grass carp was the presence of long and wavy mucosal folds and wide diameter of the lumen. This wide diameter of the lumen may serve in increase of storage capacity of food for longer periods to complete the process of digestion and absorption [12].

Mercy and Monsefi $[13,14]$ believed that the number of mucosal folds depend on the nature of foods. Our results revealed that the number and height of mucosal folds were high in the anterior intestine of grass carp. These findings may result in an increase in the retention time of food and subsequently increasing the digestion of substances by pancreatic juices and muco-substances of goblet cells, these findings are in consistent with those observed by Unal and Mokhtar $[15,16]$ in Cyprinidae.

In the present work, the wall of the anterior intestine of grass carp showed many wavy folds that could delay the speed of the intestinal movement, which probably allow for partial retention of semi-digested food for effective digestion and absorption. Such wavy folds may enable the fish to increase the exposure time of the semi-digested food to the surface area of intestinal mucosa. Similar observations were recorded in gold fish by Hiroshi [17] and in Oreochromis mossambicus by Mandal et al. [18].

From observations of the present study, the anterior intestine was lined by simple columnar epithelium, goblet cells and enteroendocrine cells. The existence of numerous microvilli on the enterocyte surface and the presence of neutral muco-substances in both fish species might be related to the absorptive function.

The increases in height of epithelium suggest the absorptive function of the surface epithelium. Rombout et al. [19] confirmed that the enterocytes of the anterior segment of the intestine of grass carp are involved in absorption of fatty acids.

From the present investigation, oval shaped enteroendocrine cells that stained positive to Grimelius were present in the anterior intestine and most of them reached to the lumen. Depeyre and Pan $[20,21]$ reported that gastrin, gastric inhibitory peptide, glucagon, pancreatic polypeptide, substance P, VIP and secretin endocrine cells were found in gut of grass carp, which had an elongated shape. They added that most of cells were of open type, this indicate that the gut contents may stimulate or inhibit peptide release from the basal part of the cell, by acting on their apical part.

In conclusion, the present study described the morphological features of the anterior intestine of grass carp and indicated that it had a wide luminal diameter and a great number and height of mucosal folds. The anterior intestine was lined by enterocytes covered by microvilli, intercalated with goblet cells, wandering lymphocytes and enteroendocrine cells. Immunohistochemstery to these enteroendocrine cells is recommended.

\section{Conclusion}

At the end of this research work, we can conclude that, seam strength of dyed apparels is less than that of un-dyed apparels. It is because of undergoing various stages in dyeing process. Different factors of sewing influence the seam strength on dyed apparels individually. The performance of apparels mainly depends on seam and stitch as well as different sewing factors. Here we also found that loss of seam strength for lapped seam is less than that of superimposed seam. So the fashion apparels in which lapped seam is mainly used, are more durable. To cope with the modern fashion era, we have to go through the fashion garments/apparels. And we also need to concentrate on the processes involved in making this fashion garments.

\section{References}

1. Guillary V, Gasaway RD (1978) Zoogeography of the grass carp in the united states. Transactions of the American Fisheries Society 107: 105-112.

2. Fiertak A, Kilarski WM (2002) Glycoconjugates of the intestinal goblet cells of four cyprinids. Cell Mol Life Sci 59: 1724-1733.

3. Morrison CM, Wright JR (1999) A study of the histology of the digestive tract of the nile tilapia. Journal of Fish Biology 54: 597-606.

4. Xiong D, Zhang L, Yu H, Xie C, Kong Y, Huo B, Liu Z, et al. (2010) A study of morphology and histology of the alimentary tract of glyptosternum maculatum (sisoridae, siluriformes). Acta Zoologica 118: 211-221.

5. Gehrke PC (1988) influence of gut morphology, sensory cues and hunger on feeding behaviour of spangled perch, leiopotherapon unicolor (guunther, 1859) (percoidei, teraponidae). Journal of Fish Biology 33: 189- 201.

6. Albrecht MP, Ferreira, MFN, Caramaschi, EP (2001) Anatomical features and histology of the digestive tract of two related neotropical omnivorous fishes (Characiformes; Anostomidae). Journal of Fish Biology 58: 419-430.

7. Murray HM, Wright GM, Goff GP (1996) A comparative histological and histochemical study of the post-gastric alimentary canal from three species of pleuronectid, the atlantic halibut, the yellowtail flounder and winter flounder. Journal of Fish Biology 20: 187- 206.

8. Fugi R, Agostinho AA, Hahn NS (2001) Trophic morphology of five benthicfeeding fish species of a tropical floodplain. Revista Brasileira de Biologia 61: 112-120.

9. Abdulhadi $\mathrm{HA}(2005)$ Some comparative histological studies on alimentary tract of tilapia fish (tilapia spilurus) and sea bream (mylio cuvieri). Egyptian Journal of Aquatic Research 31: 387-397.

10. Logothetis EA, Horn MH, Dickson KA (2001) Gut morphology and function in atherinops affinis (teleostei: atherinopsidae), a stomachless omnivore feeding on macroalgae. Journal of Fish Biology 59: 1298-1312.

11. Bancroft JD, Steven A (1996) Theory and practice of histological techniques (4thedn.) Churchill Livingstone, New York.

12. Mir IH, Channa A (2010) A scanning electron microscopic examination of the intestinal Schizothorax curvifrons Heckel. Journal of Fisheries and Aquatic Science 5: 386-393.

13. Mercy TV, Pillal NK (1985) The anatomy and histology of the Alimentary tract of the blind catfish Horaglanis krishnai Menon. International Journal of Speleology 14: 69-95.

14. Monsefi M, Gholami Z, Esmaeili H (2010) Histological and morphological studies of digestive tube and liver of the persian tooth-carp, aphanius persicus (actinopterygii: cyprinodontidae). IUFS Journal of Biology 69: 57-64.

15. Unal G (2001) Histological study of the organogenesis of the digestive system and swim bladder of the chalcalburnus tarichi pallas, 1811 (cyprinidae). Turkish Journal of Zoology 25: 217-228. 
Citation: Mokhtar DM, Abd-Elhafez EA, Hassan AH (2015) Light and Scanning Electron Microscopic Studies on the Intestine of Grass Carp (Ctenopharyngodon idella): I-Anterior Intestine. J Aquac Res Development 6: 374. doi:10.4172/2155-9546.1000374

Page 5 of 5

16. Mokhtar DM (2015) Histological, histochemical and ultrastructural characterization of the pancreas of the grass carp (Ctenopharyngodon idella). Eur J Anat 19: 145-153.

17. Hiroshi I, Yamamoto T (1984) Morphological studies of the goldfish hindgut mucosa in organ culture. Cell Tissue Res 238: 523-528.

18. Mandal DK, Chakrabarti P (1996) Architectural pattern of the mucosal epithelium of the alimentary canal of notopterus notopterus (pallas) and oreochromis mossambicus (peters) a comparative study. Acta Ichthyologica et

Piscatoria 1: 15-22.
19. Rombout JHWM, Lamers CHJ, Helfrich MH, Dekker A, Thiele JJ (1985) Uptake and transport of intact macromolecules in the intestinal epithelium of carp (caprinus carpio I.) and the possible immunological implications. Cell Tissue Res 239: 519-530.

20. Noaillac-Depeyre J, Hollande E (1981) Evidence for somatostatin, gastrin and pancreatic polypeptide-like substances in the mucosa cells of the gut in fishes with and without stomach. Cell Tissue Res 216: 193-203.

21. Pan QS, Fang ZP, Zhao YX (2000) Immunocytochemical identification and localization of APUD cells in the gut of seven stomachless teleost fishes. World J Gastroenterol 6: 96-101. 